\title{
Forensically important insects associated with the decomposition of mice carrion in Bangladesh
}

\author{
Maidul Islam, Asma Hossain, Md. Golam Mostafa* and Md. Monwar Hossain \\ Department of Zoology, Jahangirnagar University, Savar, Dhaka-1342, Bangladesh
}

\begin{abstract}
Investigations on the incidence, abundance and succession of some forensically important insects associated with mammalian carrion and their role in the decomposition of the carrion were carried out in Jahangirnagar University campus, Savar, Bangladesh. A total of twelve insect species under ten insect families belonging three orders were collected and identified during this study. The ten families viz Calliphoridae, Muscidae, Piophilidae, Sarcophagidae under the order of Diptera, the family Formicidae under the order of Hymenoptera and Silphidae, Cleridae, Histeridae and Dermestidae under the order of Coleoptera were found in mice carrion. The most abundant insects were Formicidae (55.5\%) followed by Muscidae (21. $21 \%$ ) and Calliphoridae (10.3\%). They appeared at the first stage but Dermestidae was recorded at the last stage of decomposition of the carcass. This study on mice/mammalian system could be followed by researchers and might contribute to the medico-legal purposes as well as could impart knowledge to develop a biomonitoring model in Bangladesh.
\end{abstract}

Key words: Forensic, insects, mice carrion, decomposition.

\section{INTRODUCTION}

Forensic entomology is an area of entomology, which applies insects and other arthropods in criminal investigations (Catts \& Goff, 1992). The insects found in a decomposing vertebrate corpse or carrion can be used to estimate the time of death i.e., time interval between death and corpse discovery, also called postmortem index (PMI), movement of the corpse, manner and cause of death and association of suspects at the death scene (Sukontason et al., 2007). This technique has become an important tool in criminal investigations (Joseph et al., 2011). Forensically-important insects also play a significant role in disposing of garbage, and they are the primary fauna associated with carrion (Goff and Odom, 1987; Payne, 1965; Tantawi et al., 1996). It is reported that there is an assemblage of insect species that are attracted to decomposing animals and play an active role in the decay process (Anderson \& Cervenca, 2001; Lord, 1992). Youngsteadt et al. (2015) examined a novel ecosystem service relevant to urban public health and esthetics as well as the consumption of littered food waste by insects. They estimated that insects alone could remove $4.0-6.5 \mathrm{~kg}$ of food per year in a single street median, reducing its availability to less desirable fauna such as rats, crows etc. Since many scavenging necrophagous and decomposing insects are common in urban areas, this group of organisms has the potential to reduce the public health risks, esthetic, and financial burden of littered food waste by diverting it from undesirable vertebrates and from

\footnotetext{
*Corresponding author. E-mail: bdmostafa@yahoo.com
} 
landfills. This potential might vary across the urban landscape, because arthropod diversity and species composition are sensitive to urbanization and to habitat type within the urban matrix (Youngsteadt et al., 2015). Certain species under the order of Diptera and Coleoptera represent the majority of the total necrophagous fauna found on carrion (Greenberg 1991; Payne, 1965). The decomposition of dead body starts firstly through the action of microorganisms such as fungi and bacteria, followed by the action of a series of insects, with the predominance of the sarcosaprophagous insects (Nuorteva, 1977). Typically, necrophagous flies under the families of Calliphoridae, Sarcophagidae and Muscidae first and rapidly invade animal carrion, which results in the presence of huge number of fly eggs and larvae and thus provide an abundant food supply for predacious beetles such as Silphids, Staphylinids and Histerids (Catts \& Goff, 1992). Upon death, the animal body undergoes natural changes, going through different stages of decomposition that attract the necrophagous insects for feeding and reproduction. According to Bornemissza (1957), the decomposer community of a carcass goes through a process of ecological succession. Therefore, the insects arrive in a determined sequence, producing an addition and/or substitution of species. Even by studying the sequence as well as their preference for the different stages of decomposition, and the meteorological data, the postmortem interval (PMI) as well as other forensic aspects such as the cause of death could be understood (Catts \& Goff, 1992; Anderson, 1997). Different insect species under the families of Piophilidae, Cleridae and Nitidulidae are typically associated with the carcass during the later stages of decay and the Dermestedae are attracted to the dry remains (Payne \& King, 1970; Smith, 1986; Tantwi et al., 1996). Since many of these carrion insects are attracted during these different stages of decomposition, it has been shown that carrion is invaded by certain insect species in a typical sequence or succession (Anderson \& Vanlaerhoven, 1996; Bourel et al., 1999). Anderson and Van Laerhoven (1996) monitored $22 \mathrm{~kg}$ pig carcasses for more than nine months after death in an open sunlit, rural area in southwestern British Columbia. Early \& Goff (1986) and Tullis \& Goff (1987) used small carrion in tropical areas and reported that insect colonization lasted up to three months after the placement of carcass.

Although a voluminous number of investigations on the forensically-important carrionassociated arthropods have been reported throughout the world, in Bangladesh such reports are so far not available. Therefore, the present study focused on the incidence, abundance, succession of the insects on mice carrion in Bangladesh condition. It investigated the timing of arrival and duration of stay of these arthropod species over the entire decay process of animal carcasses with a view to achieving a medico-legal tool as well as the biomonitoring agents to forecast the potential environmental hazards and deal with some other forensic aspects.

\section{MATERIALS AND METHODS}

Study site and Time: The study was carried out at Jahangirnagar University campus in Savar, Dhaka from March to May in the year of 2011. The study site was in a natural habitat in inside the Botanical Garden of Jahangirnagar University campus. The area was surrounded by shrubs and trees and there was a lake beside the study area. The site was 
selected to ensure limited public access to minimize potential human interference, allowing natural insects association with mice carrion.

Mammalian carrion: In order to understand the insects associated with a human or other mammalian carcass, dead bodies of mice were laid out on the ground. For this purpose, dissected mice, which were raised in the animal house and used for some anatomical studies of the Department of Pharmacy, Jahangirnagar University were placed on the ground. For avoiding interference of vertebrate scavengers such as dogs, jackals, mongooses, predatory lizards etc., mice dead bodies were covered by cages (30"x20"x20") made of steel. Arthropods could move easily into these cages (Fig. 1). For each study one kilogram for each of mice carrion was placed in every cage separately.

Sampling: The incidence, succession, abundance and decomposition were studied by recording the timing of arrival and duration of stay of carrion insects and these data were compared to the insect activities in carcasses. During each trial, insects were collected using aspirator, sweeping net, and also by hand-picked using forceps from the cages. Using these methods, insects were sampled from mice carcasses every day until the complete decomposition of the supplied items. All insects were collected and subsequently preserved dry or in ethanol. Samples were sorted and identified to mainly up to family level first and to some extent some insects were subsequently identified to the species level. However, due to the enormous numbers of insects collected, only species having recognized forensic relevance were documented to assess arthropod activities.

Temperature and Humidity: Since arthropod activities and the decomposition of the supplied items are influenced by temperature and humidity, temperature and humidity data were recorded every day during trial from 9:00 AM to 6:00PM.

\section{RESULTS AND DISCUSSION}

Abundance and succession of insects and decomposition of mice carrion: The fresh stage of decomposition of mice carrion started from the first day of placement of dead mice. The average air temperature and humidity during the first trial (March) was $28.85^{\circ}$ $\mathrm{C}$ and $63.89 ; 2^{\text {nd }}$ trial (April) $30.18^{\circ} \mathrm{C}$ and 84.82 and $3^{\text {rd }}$ trial (May) $30.30^{\circ} \mathrm{C}$ and 85.44 respectively. The fresh stage of decomposition was characterized by the arrival of necrophagous blowflies and flesh flies.

A total of 12 species of the families namely Calliphoridae, Sarcophagidae, Muscidae, Piophilidae, Cleridae, Dermestidae, Histeridae, Sepsidae and Formicidae were collected in this study. Among the families, Formicidae (55.50\%), Musidae $(21.21 \%)$ and Calliphoridae (10.3) were most abundant insects found on corpses (Table 1). Their incidence, abundance, succession and the decomposition rate of mice carcasses were recorded weekly which were as follows: 


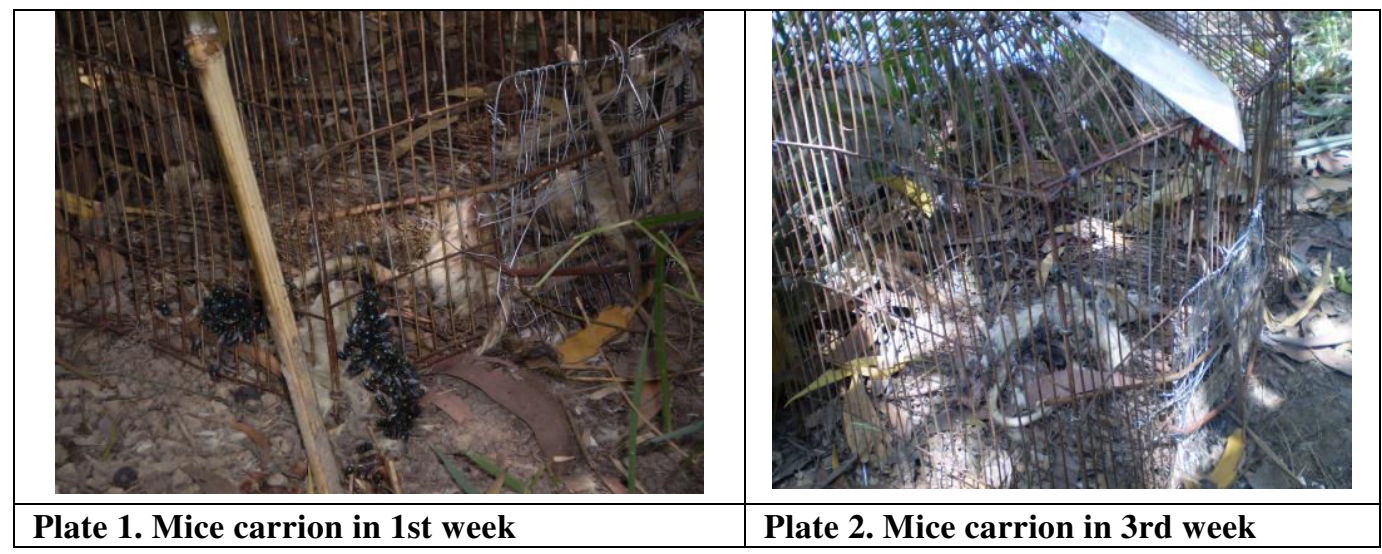

$\mathbf{1}^{\text {st }}$ week: The arrival of insects started from the first day of placement of dead mice at the study sites. Calliphorids were the first to arrive among the insects (Plate 1). They appeared within ten minutes of placement of mice carrion. Their abundance was $10.3 \%$. The arrival of other insects occurred within 1 hour of placement of the carrion. The adult Calliphorids had colonized and oviposited on all mice carcasses within 5 hours of placement. On the first day, from the hand-picked samples, the dominant species was Calliphorids in all the trials. The incidence of other insects includes flesh flies, house flies in mice carrion. The adult Calliphorids were observed all over the cages, carcasses, and in the surrounding grassy area. Eggs and early and late first instar larvae of Calliphorids extensively covered the head areas of the carcass. Eggs and larvae were especially concentrated in and around the mouth and nostrils, under the eyelids and behind and inside the ears and in chest wounds. Adult blow flies also laid eggs in the head and early and late first instar larvae were also very numerous in these areas.

Adult Musca domestica, Sarcophaga sp., and Lucilia illustris, were observed and collected from the carcasses throughout the first week in all the trials. Sepsidae under the order Diptera were also observed throughout the decay process in all the trials. At this time, the carcasses showed expanded head and abdominal area and the yellowish colour on day 3 and bloat started on day 4. Decay started on day 6 and Piophilidae were observed flying and crawling on top and underneath the carcasses. Black ants and red ants under the family Formicidae $(55.5 \%)$ were the dominant species in mice carrion throughout the decay process. They were observed to act as predators and fed on larvae and pupae of Calliphorids, Sarccophagids, and Muscids.

Some carcasses were extremely distended in the area of abdomen and the area was subsequently filled with eggs and larvae. Adult Calliphorids, eggs, and first and second instar larvae were observed in the mouths, and in the wounded areas of all of the mice. The head area of the carrion was blanketed with maggot activity.

$2^{\text {nd }}$ week: The peak maggot period occurred during the $2^{\text {nd }}$ week in all trials. There were still hundreds of larvae of Calliphorids, Sarcophagids and Muscids moving and feeding in the carcasses. The majority of Calliphorid larvae were found within the second week of 
mice placement. The number of maggots collected by hand-picking was variable. In this week, advance decay occurred and much of the skin of the carcass was dried on the head and decreased number of insect activity was apparent there.

The pupae of Calliphorids and Muscids were first observed on Day 8 and the completion of development for these flies took 14 to 22 days. By day 13, the activity of Calliphorid larvae decreased substantially and there was a considerable decrease in their numbers on the carcasses.

Many other insects, such as adult Piophilids, Sepsids, Formicids, Muscids, Clerids, Histerids and various beetle larvae were actively moving around in the pasty areas of the carcasses.

$3^{\text {rd }}$ week: Calliphorid larvae were still observed on Day 15 and 16 but very less in number than those in the $1^{\text {st }}$ and $2^{\text {nd }}$ week (Plate 2). By Day 15, maggot activity in the carrion had decreased dramatically. Pupae of Calliphorids and Muscids were observed and collected by hand-picking throughout the $3^{\text {rd }}$ week in all the trials. Silphids, Clerids and Histerids were first observed in mice carcasses on Day 14 to 16 and remained prevalent until the decay process completed. Dermestids were first observed on Day 18 in mice carrion and found feeding on carrion for the rest of the decay process.

$4^{\text {th }}$ week: This was the post-decay stage and the mice carcass was found completely dried in this week. Adult and larval Coleopterans such as Dermestes sp., Hister nomus, Silphids, mostly Necrodes sp. were observed during this time. Many of the Clerids such as Necrobia sp. inhabited the drier regions of the carcasses. These beetles were observed and collected from day 6 to the rest of the decay process.

$5^{\text {th }}$ week: This period was the final stage of decomposition. Mice carcasses were found completely decomposed within very beginning of the $5^{\text {th }}$ week. Species composition and diversity were found very less in this period. A few Dermestes sp. activity was observed during this period.

Table 1. Abundance of forensic insects associated with mice carrion

\begin{tabular}{l|r|r|r|r|r|r}
\hline \multirow{2}{*}{ Family } & \multicolumn{7}{c}{ Abundance of insects(Number) } \\
\cline { 2 - 7 } & 1st Trial & 2nd Trial & 3rd Trial & Total & Average & Percentage \\
\hline Calliphoridae & 253 & 316 & 196 & 765 & 255 & 10.3 \\
Piophilidae & 47 & 51 & 41 & 139 & 46.33 & 1.87 \\
Muscidae & 674 & 563 & 339 & 1576 & 525.33 & 21.21 \\
Sarcophagidae & 36 & 56 & 18 & 110 & 36.66 & 1.48 \\
Silphidae & 39 & 51 & 27 & 117 & 39 & 1.57 \\
Dermestidae & 47 & 69 & 30 & 146 & 48.66 & 1.96 \\
Cleridae & 25 & 43 & 25 & 93 & 31 & 1.25 \\
Histeridae & 19 & 39 & 11 & 69 & 23 & 0.92 \\
Sepsidae & 76 & 73 & 29 & 178 & 59.33 & 2.4 \\
Formicidae & 1623 & 1576 & 924 & 4123 & 1374.33 & 55.5 \\
\hline Grand Total & \multicolumn{7}{c}{7429} \\
\hline
\end{tabular}


Abundance of forensic insects: Three kinds of insects such as predators, necrophagous and cryptozoics were found on corpses in this study. The family Formicidae was the predators because they were involved in prey on other insects. Necrophagous were species that fed on debris and corpse or carcass tissue. These included the family Dermestidae and Histeridae. The insects, which sheltered in, on or under carcasses and corpses were cryptozoics, which were under these included the family of Calliphoridae. It was similar to the findings of Keh (1985) who classified insects in corpses and carcasses according to their roles as predators and parasitoids, necrophagous and cryptozoics.

In total, 10 insect families under three orders were collected and identified in mice carrion during this study. The insect families-Calliphoridae, Muscidae, Piophilidae, Sarcophagidae and Sepsidae were under the order of Diptera, the family Formicidae under the order of Hymenoptera and Silphidae, Cleridae, Histeridae and Dermestidae were under the order of Coleoptera in mice carrion. Other researchers have shown varying numbers of insects collected from different types of corpses. De Jong \& Chadwick (1999) reported a total of 53 arthropod species from rabbit carrion at different elevations in Colorado. Watson \& Carton (2003) reported 93 arthropod species associated with black bear, deer, alligator and pig carrion in Louisiana. Early and Goff (1986) reported 133 arthropod species from cat's carrion in O'ahu, Hawaii, USA.

Table 2. Abundance of insects in mice carrion on week basis

\begin{tabular}{|c|c|c|c|c|c|c|c|c|}
\hline Order & Family & $\begin{array}{l}\text { Common } \\
\text { name }\end{array}$ & Genus/species & $\begin{array}{l}\text { Abun } \\
\text { dance } \\
\text { in } 1^{\text {st }} \\
\text { week }\end{array}$ & $\begin{array}{l}\text { Abund } \\
\text { ance } \\
\text { in 2nd } \\
\text { week }\end{array}$ & $\begin{array}{l}\text { Abund } \\
\text { ance } \\
\text { in } 3^{\text {rd }} \\
\text { week }\end{array}$ & $\begin{array}{l}\text { Abun } \\
\text { dance } \\
\text { in } 4^{\text {th }} \\
\text { week }\end{array}$ & $\begin{array}{l}\text { Abun } \\
\text { dance } \\
\text { in } 5^{\text {th }} \\
\text { week }\end{array}$ \\
\hline \multirow[t]{5}{*}{ Diptera } & Calliphoridae & Blow fly & $\begin{array}{l}\text { Calliphora } \\
\text { sp. } \\
\text { Luclia } \\
\text { illustris }\end{array}$ & 253 & 191 & 80 & --- & --- \\
\hline & Sarcophagidae & Flesh fly & Sarcophaga & 36 & 21 & 15 & --- & --- \\
\hline & Muscidae & House fly & $\begin{array}{l}\text { Musca } \\
\text { domestica }\end{array}$ & 276 & 253 & 137 & ---- & --- \\
\hline & Piophilidae & Cheese Fly & $\begin{array}{l}\text { Piophila } \\
\text { Casei }\end{array}$ & 25 & 22 & 17 & ---- & ---- \\
\hline & Sepsidae & $\begin{array}{l}\text { Scavenger } \\
\text { flies }\end{array}$ & $\begin{array}{l}\text { Allosepsis } \\
\text { indica }\end{array}$ & 161 & 180 & 124 & 148 & 52 \\
\hline $\begin{array}{l}\text { Hymen } \\
\text { optera }\end{array}$ & Formicidae & Ants & $\begin{array}{l}\text { Solenopsis } \\
\text { mandibularis }\end{array}$ & 376 & 458 & 257 & 387 & 140 \\
\hline & & & $\begin{array}{l}\text { Ectatomma } \\
\text { brunneum }\end{array}$ & & & & & \\
\hline \multirow[t]{4}{*}{$\begin{array}{l}\text { Coleop } \\
\text { tera }\end{array}$} & Silphidae & $\begin{array}{l}\text { Carrion } \\
\text { beetle }\end{array}$ & Necrodes sp. & --- & --- & --- & 21 & 8 \\
\hline & Cleridae & --- & Necrobia sp. & --- & --- & --- & 13 & 7 \\
\hline & Histeridae & $\begin{array}{l}\text { Clown } \\
\text { beetle }\end{array}$ & Hister nomus & --- & --- & --- & 11 & 5 \\
\hline & Dermestidae & Hide beetle & $\begin{array}{l}\text { Dermestes } \\
\text { maculatus }\end{array}$ & --- & --- & 12 & 26 & 15 \\
\hline
\end{tabular}


Table. 3. Succession of forensic insects and the decomposing status of mice carcass

\begin{tabular}{l|l|l|l|l|l}
\hline Order & Family & Arrival day & $\begin{array}{l}\text { Decomposition } \\
\text { status of the } \\
\text { carcass }\end{array}$ & $\begin{array}{l}\text { Stay in } \\
\text { days }\end{array}$ & $\begin{array}{l}\text { Decomposition } \\
\text { status of the } \\
\text { carcass }\end{array}$ \\
\hline Hymenoptera & Formicidae & $1 \mathrm{st}$ & Fresh & $25-28$ & Post decay \\
Diptera & Calliphoridae & $1 \mathrm{st}$ & Fresh & $15-22$ & Advance Decay \\
Diptera & Muscidae & $1 \mathrm{st}$ & Fresh & $15-20$ & Advance Decay \\
Diptera & Sarcophagidae & $1 \mathrm{st}-2 \mathrm{nd}$ & fresh & $10-15$ & Advance Decay \\
Diptera & Piophilidae & 4 th-6th & Bloat & $7-14$ & Decay \\
Diptera & Sepsidae & 5 th & Bloat & $26-28$ & Post decay \\
Coleoptera & Silphidae & 6 th & Decay & $13-15$ & Advance Decay \\
Coleoptera & Histeridae & $6-8$ th & Decay & $25-28$ & Post decay \\
Coleoptera & Cleridae & 6 th 9 th & Decay & $25-28$ & Post decay \\
Coleoptera & Dermestidae & 18 th -20th & Advance Decay & $28-35$ & Decomposed \\
& & & & \\
\hline
\end{tabular}

Mice carrion

Insect families

Decomposed

Calliphoridae $>$ Formicidae $>$ Muscidae $>$ Sarcophagidae $>$ Piophilidae $>$ Sepsidae $>$ Histeridae $>$ Cleridae $>$ Dermestidae

Fig. 3. Diagram showing the sequence of succession in the decomposition of mice carcass

Succession of insects on mice carrion: The sequence of insect succession (Fig. 3) observed in the present study followed similar pattern observed by some researchers such as Joseph et al. (2011) and Smith (1986). Joseph et al. (2011) reported that the insects involved in the forensic investigations were true flies or Diptera. The predominant species in this order are Calliphoridae (blow flies), Sacrophagidae (flesh flies) and Muscidae (house flies). However, there are reported differences in the species of insects involved with the decomposing corpse in different habitats and environments. Tullis \& Goff (1887) recorded a total of 45 species of arthropods under 10 orders, 27 families, and 40 genera but Amendt et al., (2004) found forensic insects mainly from the species of the order Diptera (flies) and Coleoptera (beetles). A careful examination can reveal species variation, as species associated with one type of habitat present on a corpse is found to be different from those when the corpse is transported after death. According to Smith (1986) four categories of insects can be found on decomposing carrion: i) Necrophagous species feeding on the carrion; ii) Predators and parasites feeding on the necrophagous species: this group also contains schizophagous species which feed on the body first and which become predaceous on the later stages; iii) Omnivorous species feeding on the carrion and other arthropods like ants, wasps and some beetles; iv) Other species like springtails and spiders which use the corpse as an extension of their environment (Joseph et al., 2011). The necrophagous flies, primarily the Calliphorids, Sarcophagids and Muscids predominated in the carcasses. Predators of these species such as the Silphidae, Histeridae and Formicidae began to arrive in the sequence in response to the presence of 
huge numbers of eggs, larvae and adult flies (Gill, 2005). As the decomposition of the carrions was in progress, they became more favourable to species that were attracted to the later stages of decay and primarily species of Silphidae, Cleridae, and Dermestidae, colonized the carcasses. Anderson and Van Laerhoven (1996), Payne (1965), Early \& Goff (1986), Tabor et al. (2004) and Grassberger and Frank (2003) observed a number of basic similarities in arthropod succession with major differences being in the arrival sequence of different species within these insect families. Anderson \& Van Laerhoven (1996) found that L. illustris under the family of Calliphoridae arrived within minutes and eggs were laid within one hour of death. Piophila casei was observed on first week and then up to 14 days after death. Watson \& Carlton (2003) found P. regina as the latest Calliphorid species to arrive on swine in their spring study (Day 3) and by Day 4 was either the only species or the dominant species at all sites.

In all three trials of this study, adult Piophilidae were observed and collected on first week. During $1^{\text {st }}, 2^{\text {nd }}$ and $3^{\text {rd }}$ trial, S. nigriceps and P. case $i$ were present on mice carrion only five days after death. This observation was most consistent with Anderson \& Van Laerhoven (1996).

Two species of Silphids were collected during this study. Adult Necrodes sp. and Necrobia sp. were collected in the middle of the decay process in the mice. Other researchers have recorded silphids arriving both early and later in the decay process (Anderson \& Van Laerhoven, 1996; Payne \& King, 1970; Tabor et al., 2004).

Adult and larval Dermestidae were observed in mice carrion at the end of $3^{\text {rd }}$ week during the later stages of advanced decay. Anderson \& Van Laerhoven (1996) collected larvae as early as 21 days after death; dermestids were commonly collected 43 days after death in their study.

Payne \& King (1970) reported 28 species of histerids from carrion collected at various times during four years of research; however, Anderson \& Van Laerhoven (1996) reported that only one species was collected from soil samples during the dry remains stage in British Columbia, Canada.

Decomposition of mice carrion: Decomposition of mice carcasses was accomplished after more than four weeks after placement of the carrion. Payne (1965) showed that insect colonization time on small pig carrion was completed within four weeks. In Colorado, De Jong and Chadwick (1999) studied the decomposition and arthropod succession of rabbit carrion (mean $1.62 \mathrm{~kg}$ ) at various elevations and recorded insect colonization for a total of 51 days. In Louisiana, Watson \& Carlton (2003) studied the spring succession of insects and recorded insect activity on deer and swine until two months after carcass placement.

During this study, the process of decomposition was observed very closely and enormous number of insects was found to contend with, especially during the peak maggot period for each trial. Approximately $90 \%$ of the total maggots were collected during the second 
week of placement. These maggots were observed feeding on mice carrion and played a significant role in the process of decomposition. It was also observed that the movement of the Calliphorid maggots away from the mice carcasses marked the change from the decay to the advanced decay stage. Once all maggot activity ceased, it was assumed that the advanced decay stage was complete and the dry remains stage had begun. However, it was observed based on the physical state of the carcass, insect activity, the distinction between fresh, bloat decay and advanced decay were obvious and these findings were most similar to those described by Anderson \& Van Laerhoven (1996).

The differences in the sequence of insect succession and rate of decomposition as well as in resultant insect colonization with other investigations might be due to geographic location and size and type of animal carrion because many factors are reported to affect insect succession and the decomposition of carrion. Factors such as temperature, season, time of day, accessibility and physical position of a carcass, size and type of carcass, vertebrate scavengers, insect abundance and geographical distribution of the necrophagous can influence the time of arrival and the duration of stay of insects on the carrion (Anderson, 2000; Dillon, 1997; Hall \& Doisy, 1993; Tessmer \& Meek, 1996).

Since there are increased instances of applications of forensic entomologists in criminal investigations in the recent past, as part of the forensic teams Joseph et al. (2011), the results of such investigations may contribute to the medico-legal purposes and also can impart knowledge to develop a biomonitoring model in dealing with animal carrions or animal-related garbage.

\section{REFERENCES}

Amendt, J., Krettek, R. and Zehner, R. 2004. Forensic entomology. Naturwissenschaften. 91:5165.

Anderson, G.S. 1997. The use of insects to determine time of decapitation: a case-study from British Columbia. J. Foren. Sci. 42: 947-950.

Anderson, G. S. 2000a. Minimum and maximum development rates of some forensically important Calliphoridae (Diptera). J. Foren. Sci. 45: 824-832.

Anderson, G.S. and Cervenka, V.J. 2001. Insects associated with the body: Their use and analyses IN Advances in Forensic Taxonomy. Methods, Theory and Archeological Perspectives. Haglund, W. and Sorg, M. (Eds.) CRC Press. pp. 174-200.

Anderson, G.S. and Van Laerhoven, S.L. 1996. Initial studies on insect succession on carrion in southwestern British Columbia. J. Foren. Sci. 41:617-625.

Bornemissza, G.F. 1957. An analysis of arthropod succession in carrion and the effect of its decomposition on the soil fauna. Aust. J. Zool. 5(1): 1-12.

Bourel, B., Martin-Bouyer, B.L., Hedouin, B., Derout, D. and Gosset, D. 1999. Necrophilous insect succession on rabbit carrion in sand dune habitats in northern France. J. Med. Entomol. 36: 420-425.

Catts, E.P. and Goff, M.L. 1992. Forensic entomology in criminal investigations. Annal. Rev. Entomol. 37: 253-272.

De Jong, G.D. and Chadwick, J.W. 1999. Decomposition and arthropod succession on exposed rabbit carrion during summer at high altitudes in Colorado, USA. J. Med. Entomol. 36:833-845. 
Dillon, L.C. 1997. Insect succession on carrion in three biogeoclimatic zones of British Columbia. M.Sc. Thesis, Simon Fraser University, Burnaby, BC.

Early, M. and Goff, M. L. 1986. Arthropod succession patterns in exposed carrion on the island of Oï i ${ }^{1 / 2 h a u}$, Hawaiian Islands, USA. J. Med. Entomol. 23(5): 520-531.

Gill, G.J. 2005. Decomposition and arthropod succession on above ground pig carrion in rural Manitoba. Technical Report (TR-06-2005). Canadian Police Research Centre. pp 100.

Grassberger, M. and Frank, C. 2003. Temperature-related development of the parasitoid wasp Nasonia vitripennis as forensic indicator. Med. Vet. Entomol. 17: 257-262.

Goff, M.L. and Odom, C.B. 1987. Forensic entomology in the Hawaiian Islands: three case studies. The Am. J. Foren. Med. Pathol. 8: 45-50.

Greenberg, B. 1991. Flies as forensic indicators. J. Med. Entomol. 28: 565- 577.

Hall, R.D. and Doisy, K.E. 1993. Length of time after death-effect on attraction and oviposition or larviposition of midsummer blow flies (Diptera, Calliphoridae) and flesh flies (Diptera, Sarcophagidae) of medico-legal importance in Missouri. Annal. Entomol. Soc. Am. 86: 589-593.

Joseph, I., Mathew, D.G., Sathyan, P. and Vargheese, G. 2011. The use of insects in forensic investigations: An overview on the scope of forensic entomology. J. Foren. Dent. Sci. 3(2): 89-91.

Keh, B. 1985. Scope and applications of forensic entomology. Annal. Rev. Entomol. 30:137-54.

Lord, W.D., Adkins, T. R and Catts, E. P. 1992. The use of Synthesomyia nudesita (Van Der Wulp) (Diptera: Muscidae) and Calliphora vicina (Robineau-Desvoidy) (Diptera: Calliphoridae) to estimate the time of death of a body under a house. J. Agri. Entomol. 9: 227-235.

Meek, C.L. and Andis, M.D. 1983. Role of the entomologist in forensic pathology, including a selected bibliography. Bib. Entomol. Soci. Am. 1: 1-10.

Nagorsen, D.W. and Peterson, R.L. 1980. Mammal Collectors' Manual: A Guide for Collecting, Docurnenting and Preparing Mammal Specimens for Scientific Research. Life Sciences Misc. Publ., Royal Ontario Museum, Toronto, pp 79.

Nuorteva, P., Schumann, H. and Laiho, K. 1974. Studies on the possibilities of using blow flies (Dipt., Calliphoridae) as medicolegal indicators in Finland. Annal. Entomol. Fennici. 40: 70-74.

Payne, J.A. 1965. A summer carrion study on the baby pig. Sus scrofa L. Ecology. 46: 592-602.

Payne, J.A. and King, E.W. 1970. Coleoptera associated with pig carrion. Entomologists' Monthly Magazine 105: 224-232.

Smith, K.G.V. 1986. A manual of forensic entomology. Cornell University Press, Ithaca, NY.

Sukontason, K., Narongchai, P., Kanchai, C., Vichairat, K., Sribanditmongkol, P., Bhoopat, T., Kurahashi, H., Chockjamsai, M., Piangjai, S., Bunchu, N. and et al. 2007. Forensic entomology cases in Thailand: a review of cases from 2000 to 2006. Parasitol. Res. 101: 1417-1423.

Tabor, K.L., Brewster, C.C. and Fell, R.D. 2004. Analysis of the successional patterns of insects on carrion in southwest Virginia. J. Med. Entomol. 41:785-795.

Tantawi, T.I., Greenberg, B. and Ghaffar, H.A. 1996. Arthropod succession on exposed rabbit carrion in Alexandria, Egypt. J. Med. Entomol. 33: 566-580.

Tullis, K. and Goff, M.L. 1987. Arthropod succession in exposed carrion in a tropical rainforest on Oahu Island, Hawaii. J. Med. Entomol. 24: 332-339.

Watson, E.J. and Carlton, C.E. 2003. Spring succession of necrophilous insects on wildlife carcasses in Louisiana. J. Med. Entomol. 40: 338-347.

Youngsteadt, E., Henderson, R.C., Savage, A.M., Ernst, A.F., Dunn, R.R. and Frank, S.D. 2015. Habitat and species identity, not diversity, predict the extent of refuse consumption by urban arthropods. Global Change Biol. DOI: 10.1111/gcb.12791. 